Friends and Strangers 


\section{EARLY AMERICAN STUDIES}

\section{Series editors:}

Daniel K. Richter

Kathleen M. Brown

David Waldstreicher

Exploring neglected aspects of our colonial, revolutionary, and early national history and culture, Early American Studies reinterprets familiar themes and events in fresh ways.

Interdisciplinary in character, and with a special emphasis on the period from about 1600 to 1850 , the series is published in partnership with the McNeil Center for Early American Studies.

A complete list of books in the series is available from the publisher. 


\title{
Friends and Strangers
}

\author{
The Making of a Creole Culture \\ in Colonial Pennsylvania
}

John Smolenski

\section{$\overline{\text { PENN }}$}

UNIVERSITY OF PENNSYLVANIA PRESS

PHILADELPHIA · OXFORD 
Copyright (C) 20I0 University of Pennsylvania Press

All rights reserved. Except for brief quotations used for purposes of review or scholarly citation, none of this book may be reproduced in any form by any means without written permission from the publisher.

Published by

University of Pennsylvania Press

Philadelphia, Pennsylvania I9I04-4II2

Printed in the United States of America on acid-free paper

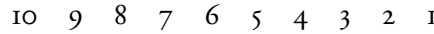

Library of Congress Cataloging-in-Publication Data Smolenski, John

Friends and strangers : the making of a Creole culture in colonial Pennsylvania/John Smolenski.

p. $\quad \mathrm{cm}$. - (Early American studies)

Includes bibliographical references and index.

ISBN 978-0-8I22-4239-3 (hardcover : acid-free paper)

I. Quakers-Pennsylvania-History. 2. PennsylvaniaEthnic relations. 3. Pennsylvania-History-Colonial period, ca. 1600-1775. I. Title.

Fi6o.F89S65 2010

$974.8^{\prime} \mathrm{O} 2-\mathrm{dc2} 2$ 20090449II 
To Steph

My Sweetie 
